EUROPA REGIONUM TOM XXVIII ROK 2016

DOI: $10.18276 /$ er.2016.28-09

\author{
EWA KASPERSKA, MARCELINA KONDRATOWICZ \\ Politechnika Koszalińska
}

\title{
Samorząd terytorialny i jego udział w organizacji imprez biegowych
}

\section{Wprowadzenie}

$\mathrm{Z}$ ainteresowanie sportem, w tym zwłaszcza bieganiem, w Polsce w ostatnich latach lawinowo wręcz rośnie. Wyrazem tego jest zwiększająca się liczba osób biegających dla relaksu w wolnym czasie, ale też liczna organizowanych imprez biegowych (biegów ulicznych). W imprezach tych, prócz zawodowych biegaczy, uczestniczących w biegu w oczekiwaniu konkretnych sukcesów (zajęcie prestiżowego miejsca), startuje wielokrotnie bardziej liczba grupa biegaczy amatorów, dla których bieg jest okazją do rywalizacji z innymi, ale też możliwości sprawdzenia siebie i swojego organizmu, sposobem na relaks, przeżyciem pasjonującej przygody, ciekawym spotkaniom towarzyskim, odwiedzeniem atrakcyjnego miejsca, czy połączeniu sportu z turystyką (często rodzinną).

Organizatorom imprez biegowych przyświecają różne cele, chociaż, co zrozumiałe, najczęściej odwołują się oni do popularyzacji sportu, rekreacji i zdrowego stylu życia. Z uwagi na charakter imprezy, a także samego organizatora oraz sposób i motywację do jej organizacji, wśród celów pojawia się też propagowanie wolontariatu, uczczenie jakiegoś wydarzenia, a w przypadku memoriałów - pamięci patrona biegu; w biegach charytatywnych jest to zbieranie funduszy na określony, szczytny cel. Część organizatorów, co też trzeba przyznać, organizując bieg w ogóle nie precyzuje jego celu.

Istotnym jest również fakt, że bieg jest silnie przypisany do miejsca jego rozgrywania, bowiem to ono decyduje często o charakterze i prestiżu imprezy. Zatem wśród celów pojawiają się również te, promujące gminę/miasto, czy re- 
gion. Dzieje się tak zwykle, gdy organizatorem, lub współorganizatorem jest samorząd lokalny. Wówczas bieg staje się doskonałym narzędziem promocji regionu, kreowania jego wizerunku, budowania atrakcyjności miejsca, ale też integracji mieszkańców i pobudzania aktywności lokalnych środowisk.

Czy jednak samorządy uświadamiają sobie związane z biegiem korzyści dla regionu i wykorzystują możliwości, jakie daje w tym zakresie masowa impreza biegowa. W jak dużym stopniu angażują się w przedsięwzięcie rozgrywane na swoim terenie? Takie pytanie zadały sobie autorki, a odpowiedź na nie uczyniły celem artykułu. Aby ją uzyskać dokonały przeglądu regulaminów imprez biegowych rozgrywanych w Polsce, zebranych w kalendarzu publikowanym na stronie wwww.maratonypolske.pl. Z uwagi na bardzo obszerny materiał badawczy (3627 imprez zarejestrowanych w 2016 r.) i mnożące się braki w danych dla imprez rozgrywanych wcześniej, badaniu poddały II pólrocze $2016 \mathrm{r}$. (1675 imprez).

\section{Imprezy biegowe}

Bieganie stało się niemal powszechnym sportem uprawianym przez amatorów w wolnym czasie, dla poprawy zdrowia, kondycji, relaksu. Jak podaje ARC Rynek i Opinia na podstawie badań zainteresowania sportem wśród Polaków, przeprowadzonych w 2015 r. ,,Jeszcze kilka lat temu bieganie było znacznie mniej popularne niż jazda na rowerze, piłka nożna czy pływanie. Teraz obserwujemy daleko idącą modę na bieganie, co czyni z tej dyscypliny numer jeden." (ARC Rynek i Opinia, 17.10.2016). Zgodnie z tymi danymi 64\% Polaków deklaruje, że uprawia sport, $44 \%$ robi to regularnie, a aż co trzeci ze sportowców amatorów to biegacz (rys. 1). Jeśli dane te są prawdziwe i przy uwzględnieniu faktu, że badanie dotyczyło pełnoletnich Polaków, grono biegaczy w Polsce liczby ok $6,5 \mathrm{mln}$ osób.

Tak duże zainteresowanie bieganiem ma swoje odzwierciedlenie w ilości organizowanych imprez biegowych. Na przestrzeni ostatnich pięciu lat ich liczba uległa podwojeniu (rys. 2). Imprezy te organizowane są wszędzie: w wielkich metropoliach (np. Maraton Warszawski), miastach (np. Bieg Mikołajów w Toruniu), w małych miasteczkach (np. Maraton Dębno), ośrodkach wiejskich (np. Bieg po plaży w Jarosławcu), a także na obszarach niezamieszkałych (np. Bieg Granią Tatr). 


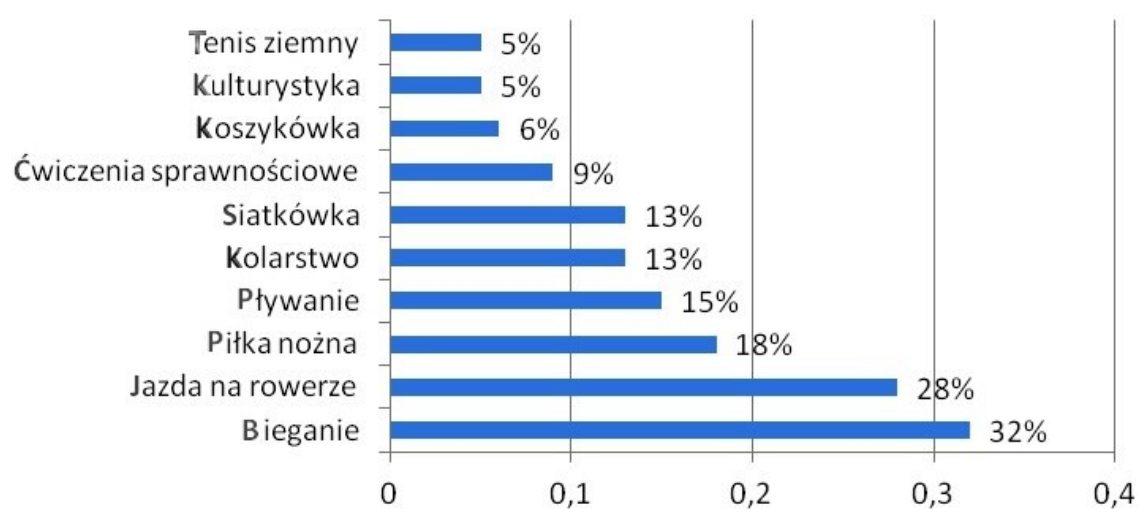

Rysunek 1. Najczęściejuprawiane dyscypliny sportowe według badań ARC Rynek i Opinia Źródło: ARC Rynek i Opinia, sierpień 2015.

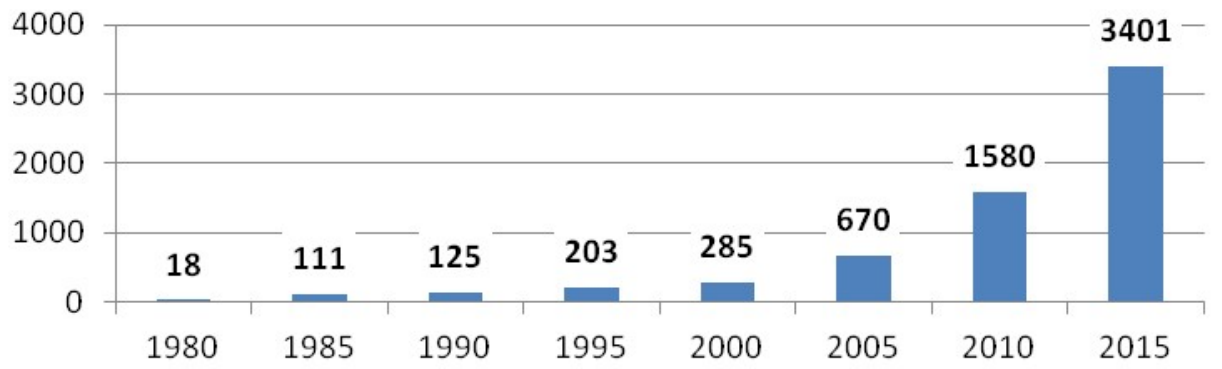

Rysunek 2. Liczba imprez biegowych w Polsce w latach 1980-2015

Źródło: Opracowanie własne na podstawie http://www.maratony polskie.pl (17.10.2016).

Imprezy biegowe charakteryzuje też olbrzymia różnorodność związana z wieloma aspektami. Mogą one dotyczyć:

- rodzaju pokonywanej trasy (bieg miejski, przełajowy, po górach, po bezdrożach),

- dystansu (ultramaratony, maratony, pólmaratony, 15, 10, 5 km, i in.),

- trudności biegu (po terenie płaskim, bagnistym, po plaży, wzniesieniach, w górach, bieg ze sztucznymi utrudnieniami),

- cykliczności (jednorazowe - okazjonalne, rozgrywane dorocznie, wieloetapowe),

- uczestników (biegi indywidualne, drużynowe, sztafety, dla dzieci),

- dedykowane określonym grupom biegaczy (np. bieg policjantów, strażaków, leśników, pracowników firm, seniorów i weteranów itp.),

- tematu przewodniego (np. Bieg po plaży w Jarosławcu, Bieg po miód, Bieg Mikołajów, Bieg na szpilkach, Bieg Walentynkowy), 
- połączenia biegu z innymi dyscyplinami (duathlon, triathlon),

- idei zorganizowania biegu (biegi charytatywne, w celu zebrania funduszy, biegi upamiętniające wydarzenia historyczne, związane $\mathrm{z}$ obchodami rocznic).

Tak duże zróżnicowanie biegów oznacza różnorodną ofertę dla biegaczy, którzy mogą rozpatrywać swoje uczestnictwo w imprezie w zależności od jej dystansu, charakteru, miejsca odbywania i wielu innych czynników. Elementem różnicującym imprezy biegowe, choć może nie tak istotnym z punktu widzenia zwykłego uczestnika, może być też cel imprezy, a także jej organizator. Wśród nich, co tu szczególnie istotne, są też samorządy terytorialne.

\section{Samorząd terytorialny i jego zadania}

Zgodnie z informacją zamieszczoną w Leksykonie budżetowym, brak jest w polskim prawie jednolitej i całościowej definicji samorządu terytorialnego. Jego pojęcie i dotyczące go regulacje należy zatem wywodzić z wielu źródeł prawa, do których w pierwszej kolejności zaliczyć należy Konstytucję RP. Jak podaje wspomniany Leksykon „Podstawowe przepisy konstytucyjne dotyczące samorządu terytorialnego zostały zamieszczone w rozdziale I. W art. 15 ujęto zasadę decentralizacji władzy publicznej, a w art. 16 zdefiniowano wspólnotę samorządową, którą tworzy ogół mieszkańców określonej jednostki podziału terytorialnego państwa. W art. 16 zawarto także formułę o udziale samorządu terytorialnego $\mathrm{w}$ sprawowaniu władzy oraz o przypisaniu mu istotnej części zadań publicznych.” (Leksykon, sejm.gov.pl, 20.10.2016). Jak podaje Czajkowska-Matosiuk ,samorząd terytorialny to forma samorządu o przymusowym charakterze członkostwa, obejmująca wszystkie osoby zamieszkałe na terenie określonej jednostki podziału terytorialnego państwa, polegająca na niezależnym od administracji rządowej zarządzaniu własnymi sprawami społeczności lokalnej.” (Czajkowska-Matosiuk 2014).

W Polsce, od 1999 r. obowiązuje trójszczeblowa struktura samorządu terytorialnego, ustanowiona mocą Ustawy z 24 lipca 1998 r. (Ustawa o podziale terytorialnym, 1998). Art.1.2. stanowi: „Jednostkami zasadniczego trójstopniowego podziału terytorialnego państwa są: gminy, powiaty i województwa”. Zgodnie z Konstytucją, ,jednostki samorządu terytorialnego mają osobowość prawną. Przysługują im prawo własności i inne prawa majątkowe" (Art. 165.1. Konstytucji RP). Każda $\mathrm{z}$ nich działa $\mathrm{w}$ imieniu własnym i na własną odpowiedzialność. 
Podstawową jednostką samorządu terytorialnego w Polsce jest gmina. (art. 164.1. Konstytucji RP). Zgodnie z art. 6. pkt.1. Ustawy o samorządzie gminnym (Ustawa 1990), do zakresu działania gminy należą wszystkie sprawy publiczne o znaczeniu lokalnym. W ramach posiadanych kompetencji gmina wykonuje zadania własne i zlecone. Zadania własne gminy dotyczą zaspokajania zbiorowych potrzeb wspólnoty gminnej i obejmują $\mathrm{m}$. in. sprawy ,...kultury fizycznej i turystyki, w tym terenów rekreacyjnych i urządzeń sportowych; (...) wspierania i upowszechniania idei samorządowej, w tym tworzenia warunków do działania i rozwoju jednostek pomocniczych i wdrażania programów pobudzania aktywności obywatelskiej; (...) promocji gminy;” (Ustawa 1990, art. 7.1.).

Zadania własne gminy mogą być wykonywane przez samorządowe zakłady budżetowe (Ustawa 2009, art. 14). Do zakładów budżetowych należy większość z około czterystu, funkcjonujących w Polsce, samorządowych ośrodków sportu i rekreacji, pozostałe (ale nieliczne) mają status prawny spółki miejskiej, lub (nieco częściej) jednostki budżetowej, finansowanej w 100\% ze środków publicznych (sportplus, 2012).

Powiat jest jednostką samorządu lokalnego i podobnie jak gmina, pełni określone ustawami zadania publiczne. Funkcje powiatu mają charakter uzupełniający i wyrównawczy w stosunku do gminy. Zgodnie z art. 4.1. Ustawy z 5 czerwca 1998 (Ustawa o samorządzie powiatowym, 1998) obejmują one m.in. obszar kultury fizycznej i turystyki, a także promocji powiatu (Ustawa 1990, art. 7.1.).

Ostatnim, trzecim szczeblem struktury samorządu lokalnego w Polsce jest województwo. Zasady jego funkcjonowania oraz obowiązki precyzuje Ustawa z 5 czerwca 1998 r. (Ustawa o samorządzie województwa, 1998). Zgodnie z jej postanowieniami, zakres działania samorządu województwa nie narusza samodzielności powiatu i gminy. Jego zadania precyzuje art. 11. 1. ustawy, który nakłada na samorząd obowiązek sformułowania strategii rozwoju województwa, uwzględniającej w m.in. cel rozwoju i kształtowania świadomości obywatelskiej i kulturowej mieszkańców, a także pielęgnowania i rozwijania tożsamości lokalnej. W swej polityce uwzględniać musi przy tym promocję walorów i możliwości rozwojowych województwa oraz wspieranie i prowadzenie działań na rzecz integracji społecznej (Ustawa o samorządzie województwa 1998, art. 11.2.).

Wszystkie samorządy terytorialne, mocą właściwych ustaw, zobowiązane są do współpracy w wypełnianiu przypisanych im zadań z samorządami innych lub tego samego szczebla, administracją rządową oraz organizacjami pozarządowymi i podmiotami wymienionymi w art. 3.3 Ustawy z 24 kwietnia 2003 r. 
o działalności pożytku publicznego i o wolontariacie (Ustawa, 2003), czyli m.in. stowarzyszeniami, fundacjami, a także spółkami akcyjnymi, z o.o. lub klubami sportowymi działającymi na podstawie przepisów Ustawy z dnia 25 czerwca 2010 r. o sporcie (Ustawa 2010).

Nałożone z mocy ustaw na samorządy terytorialne zadania oznaczają możliwość, ale i obowiązek angażowania się w przedsięwzięcia realizowane na ich obszarze, a spełniające wymienione wyżej cele. Do takich należą również silnie przypisane do miejsca masowe imprezy biegowe, które poza innymi korzyściami płynącymi $\mathrm{z}$ ich odbywania, mogą być też doskonałym narzędziem popularyzacji i promocji regionu.

\section{Miejsce samorządów terytorialnych w organizacji imprez biegowych}

W celu zbadania stopnia zaangażowania samorządów terytorialnych w organizacje imprez biegowych poddano analizie, zarejestrowane w kalendarzu biegów na stronie www.maratonypolskie.pl, biegi masowe, odbyte lub zaplanowane na II półrocze 2016 r. we wszystkich województwach w Polsce. Liczba zarejestrowanych imprez wynosiła 1675, zdobyte informacje dotyczą natomiast 964 biegów, co stanowi 57,6\% populacji. Analizie zostały poddane wszystkie wyszczególnione imprezy, jednak w przypadku pozostałych nie udało się, bądź to zidentyfikować strony $\mathrm{z}$ informacjami o biegu, bądź też regulaminu precyzującego organizatora i/lub cel imprezy. Szczegółowe zestawienie liczby imprez zarejestrowanych i sklasyfikowanych w statystykach dla poszczególnych województw prezentuje rysunek 3. Przedstawia on zarazem województwa najaktywniejsze pod względem liczby rozgrywanych tam biegów. Zdecydowaną dominacją odznacza się województwo śląskie, w którym w badanym okresie zarejestrowano 259 imprez, następnie są to: wielkopolskie (229), małopolskie (185), dolnośląskie (161) i mazowieckie (154).

Lista organizatorów biegów jest imponująca. Należą do nich bardzo różne jednostki, często też zdarza się, że jedną imprezę organizuje lub współuczestniczy w jej organizacji kilka podmiotów. Są to jednak zwykle instytucje, organizacje lub przedsiębiorstwa $\mathrm{z}$ danego obszaru. Incydentalnie wspótpracują ze sobą sąsiadujące samorządy terytorialne (jeśli już podejmują taką współpracę, to zwykle są to podmioty zrzeszone np. we wspólnym stowarzyszeniu gmin). Średnia liczba organizatorów dla wydarzeń biegowych w Polsce wynosi 2,4 
podmioty na imprezę. Dla województwa mazowieckiego jest to 3,7, dla pomorskiego 3,6, natomiast dla wielkopolskiego, opolskiego i podlaskiego - 1,7.

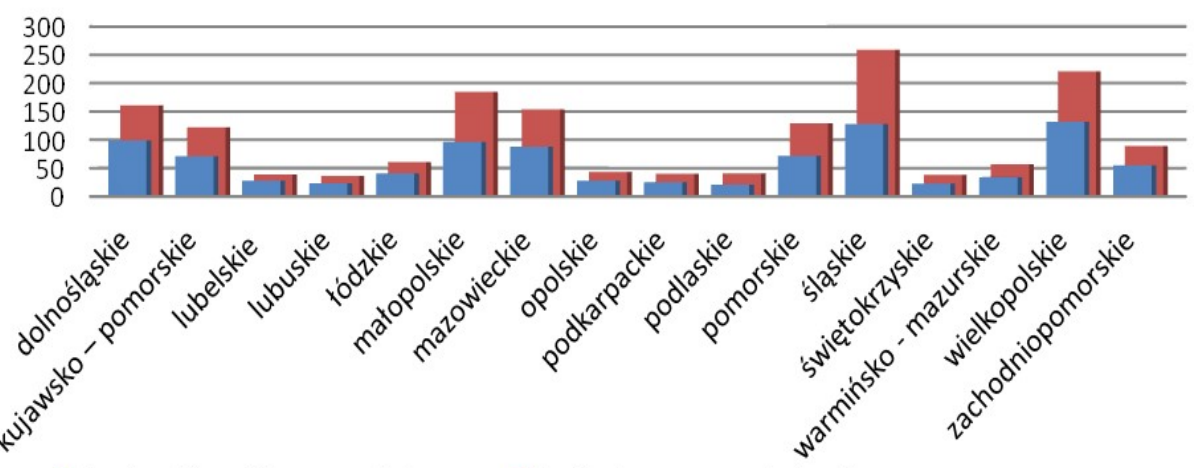

- liczba sklasyfikowanych imprez liczba imprez wg kalendarza

Rysunek 3. Liczba imprez biegowych w Polsce w II półroczu 2016 wg województw Źródło: opracowanie własne na podstawie http://www.maratonypolskie.pl (20.10.2016).

$\mathrm{Na}$ pierwsze miejsce wśród organizatorów imprez (rys. 4) wysuwają się podmioty prywatne (uczestniczyły $\mathrm{w}$ organizacji $38,6 \%$ wydarzeń) i to włánie one często są tymi organizatorami, którzy biorą się za przedsięwzięcie w pojedynkę. W przypadku części biegów należy też domniemywać, że działalność podmiotów prywatnych ma charakter komercyjny, a robią to na zlecenie innych instytucji, np. ORLEN Warsaw Marathon organizuje spółka $\mathrm{z}$ o.o. (http://www.orlenmarathon.pl, 20.10.16). Wówczas zwykle inne podmioty pełnią $\mathrm{w}$ biegu rolę patrona lub sponsora.

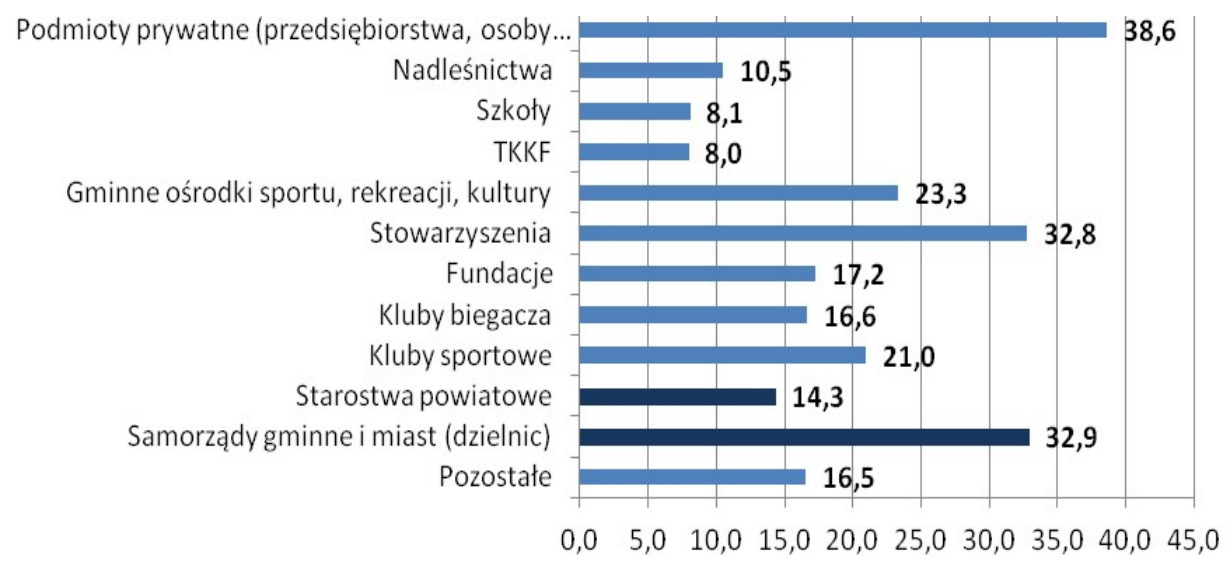

Rysunek 4. Imprezy biegowe według zaangażowania w ich organizację poszczególnych podmiotów, (\%)

Źródło: opracowanie własne na podstawie http://www.maratonypolskie.pl (20.10.2016). 
Drugie miejsce w rankingu zajmują samorządy terytorialne gmin/miast, czy w przypadku Warszawy, dzielnic (32,9\%). Tu zdarza się, że gmina jest głównym (i bywa, że jedynym) organizatorem, np. PZU Cracovia Maraton organizuje Gmina Miejska Kraków (http://www.zis.krakow.pl/regulamin-16-pzu-cm, 20.10.16). Jednak bardziej powszechne jest uczestnictwo samorządu gminy w gronie współorganizatorów lub wspólpracowników.

Kolejne miejsce zajmują powołane specjalnie w tym celu stowarzyszenia $(32,8 \%)$, np. Sport, Rekreacja i Wolontariat SFX z Koszalina, organizujący cyklicznie „Nocną Ściemę”, „Leśną Piątkę” i „Kurs na Chełmską” (http://stowarzyszenie.sfx.org.pl, 20.10.16). Udział samorządów terytorialnych w organizacji imprez powiększają starostwa powiatowe (14,3\%), łącznie z gminami stanowiąc grupę zaangażowaną w organizację najliczniejszej liczby biegów. Trzeba jednak przy tym zauważyć, że żadne ze starostw nie było wśród analizowanych regulaminów samodzielnym organizatorem imprezy biegowej, a zawsze występowały one jako współorganizatorzy.

Częstą praktyką w przypadku samorządów, jest patronat nad imprezą, który obejmuje wójt, burmistrz, prezydent lub starosta, czy wojewoda. W przypadku województw jest to zarazem jedyny zdiagnozowany sposób powiązania ich $\mathrm{z}$ imprezą, bowiem $\mathrm{w}$ żadnym $\mathrm{z}$ regulaminów nie zidentyfikowano województwa jako organizatora, czy współorganizatora imprezy.

Samorządy lokalne uczestniczą też w biegach pośrednio, tj. za sprawą zaangażowania $\mathrm{w}$ ich organizację OSiRów lub gminnych ośrodków kultury $(23,3 \%)$. Pojedyncze zawody biegowe, jak wykazała analiza, organizowały też inne samorządowe jednostki organizacyjne: ośrodki pomocy społecznej, środowiskowe domy pomocy społecznej, lokalne organizacje turystyczne, czy zarządy obiektów sportowych.

Zdecydowanie najsilniej w organizację imprez zaangażowane są jednostki samorządu terytorialnego w województwie podkarpackim (rys. 5). Ich udział wśród wszystkich organizatorów wynosi łącznie 40,3\%. Jest to jednak zarazem, obok świętokrzyskiego i lubuskiego, województwo o najmniejszej liczbie biegów. Dla pozostałych dwóch wymienionych odsetek wśród organizatorów imprez jest już jednakże znacznie niższy (odpowiednio 14,0 i 17,4\%). Województwo podkarpackie dominuje nad pozostałymi, przede wszystkim ze względu na uczestniczące w organizacji biegów gminy. Ich wskaźnik (37,1\%) jest niemal dwukrotnie większy od drugiego w rankingu ze względu na udział gmin, woje- 
wództwa wielkopolskiego (19,2\%). Wielkopolskie należy jednak do piątki „biegowych gigantów" i to właśnie w nim sklasyfikowano najwięcej imprez.

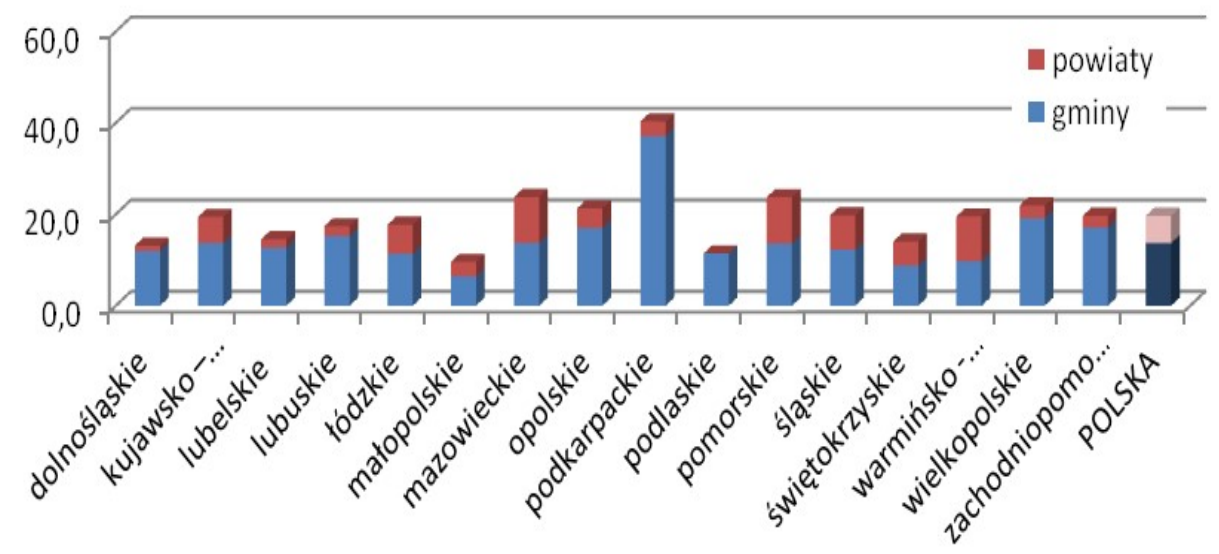

Rys. 5. Udział samorządów terytorialnych wśród organizatorów imprez biegowych, (\%) Źródło: opracowanie własne na podstawie http://www.maratonypolskie.pl (20.10.2016).

Wśród wspominanej piątki najaktywniejszych województw (wielkopolskie - 132 sklasyfikowane imprezy, śląskie - 128, dolnośląskie - 99, małopolskie 96 i mazowieckie - 88) udział gmin w organizacji imprez jest zróżnicowany. Do ich grona należy np. małopolskie, ze zdecydowanie najniższym odsetkiem imprez organizowanych lub współorganizowanych przez samorządy w skali całej Polski (9,6\% organizatorów to samorządy). Analizując zaangażowanie samorządów $\mathrm{w}$ pozostałych województwach, na uwagę zasługuje fakt, że w dolnośląskim znikoma ilość powiatów angażuje się w organizację biegów $(1,1 \%)$, a w podlaskim nie zanotowano żadnego takiego przypadku.

Duże i różnorodne jest też grono innych, nie wymienionych w zestawieniu organizatorów. Wśród nich najliczniej reprezentowane są ochotnicze straże pożarne, których w skali Polski naliczono ponad 20, a które z racji swojego charakteru również mają związki (finansowe i formalne) z samorządami.

W kontekście organizacji lub współorganizacji przez samorządy imprez biegowych istotny jest powód, dla którego powinny być one tym zainteresowane. Podstawowym jest wkład biegów w promocję regionu. Oczywistą ich funkcją, niezależnie od woli organizatorów, jest upowszechnianie wiedzy o miejscu ich odbywania. Udane imprezy biegowe, zwłaszcza te o charakterze cyklicznym, ugruntowane w świadomości zainteresowanych i mające stałe miejsce w kalen- 
darzu biegów przyciągają rokrocznie większe grono uczestników. Upowszechniają i kreują korzystny wizerunek regionu i lokalnych władz. Rosnąca liczba odwiedzających przyczynia się do ożywienia ruchu turystycznego, wydłużenia sezonu (największa liczba imprez przypada na miesiące maj, czerwiec i wrzesień), a co za tym idzie, generuje popyt na miejscowe produkty i usługi, pobudzając lokalną przedsiębiorczość i rynek pracy. Poza przejściowymi utrudnieniami organizacyjnymi oraz koniecznością zdobycia funduszy nie niosą ze sobą natomiast większych negatywów. Trudno zatem przecenić zalety takich imprez.

Aby sprawdzić, czy władze samorządowe kładą nacisk na promocję i kreowanie pozytywnego wizerunku swojego regionu prześledzono cele imprez zawarte $\mathrm{w}$ analizowanych regulaminach. Najpowszechniejszym powodem organizacji biegu, co zrozumiałe, była chęć popularyzacji sportu (zwłaszcza biegania) i zdrowego (aktywnego) stylu życia. Wśród innych pojawiały się też: upowszechnianie idei wolontariatu, upamiętnienie wydarzenia lub konkretnej osoby, zebranie środków na szczytny cel (w zależności od rodzaju biegu), a także promocja gminy/miasta, powiatu, konkretnej miejscowości lub krainy, czy też walorów przyrody w regionie (np. parku krajobrazowego) lub Lasów Państwowych i obszarów leśnych. Przy czym wiele $\mathrm{z}$ analizowanych biegów miało w swoich regulaminach zdefiniowanych kilka różnych celów. Wśród sklasyfikowanych imprez biegowych w Polsce najliczniej reprezentowany jest cel promocji gminy/miasta (rys. 6.), chociaż co ciekawe, nie zawsze współwystępuje on z samorządem gminnym jako organizatorem. Cel taki zakłada sobie część stowarzyszeń, czy fundacji, a także samorządowych jednostek organizacyjnych.

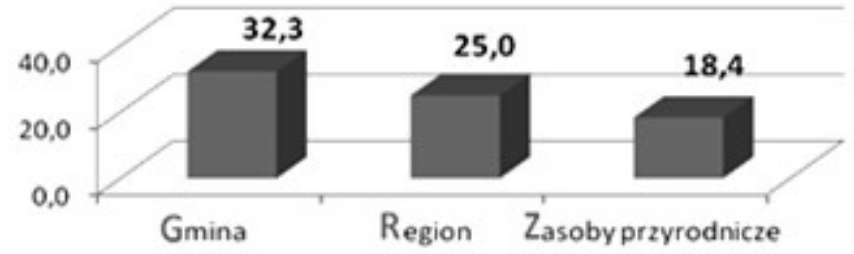

Rysunek 6. Cele promocji regionu w regulaminach imprez biegowych. (\%) Źródło: opracowanie własne na podstawie http://www.maratonypolskie.pl (20.10.2016).

Wśród województw promocja miejsca odbywania imprezy, biorąc pod uwagę wszystkie trzy kategorie (gmina, region, zasoby przyrody) najliczniej zapisana jest $\mathrm{w}$ celach imprez rozgrywanych w pomorskim (rys. 7), chociaż 
pierwszą lokatę województwo to zajmuje tylko, dla zasobów przyrodniczych (43,1\% imprez). Wśród promowania gminy i regionu na pierwszym miejscu znajduje się warmińsko-mazurskie (odpowiednio 61,8\% i 52,9\%). Niemal równie mocno promuje gminę zachodniopomorskie $(54,5 \%)$, a region podkarpackie (52\%). Zasoby przyrodnicze cieszą się słabszym zainteresowaniem organizatorów. Na drugim miejscu (z notą 32\% imprez) plasuje się śląskie.

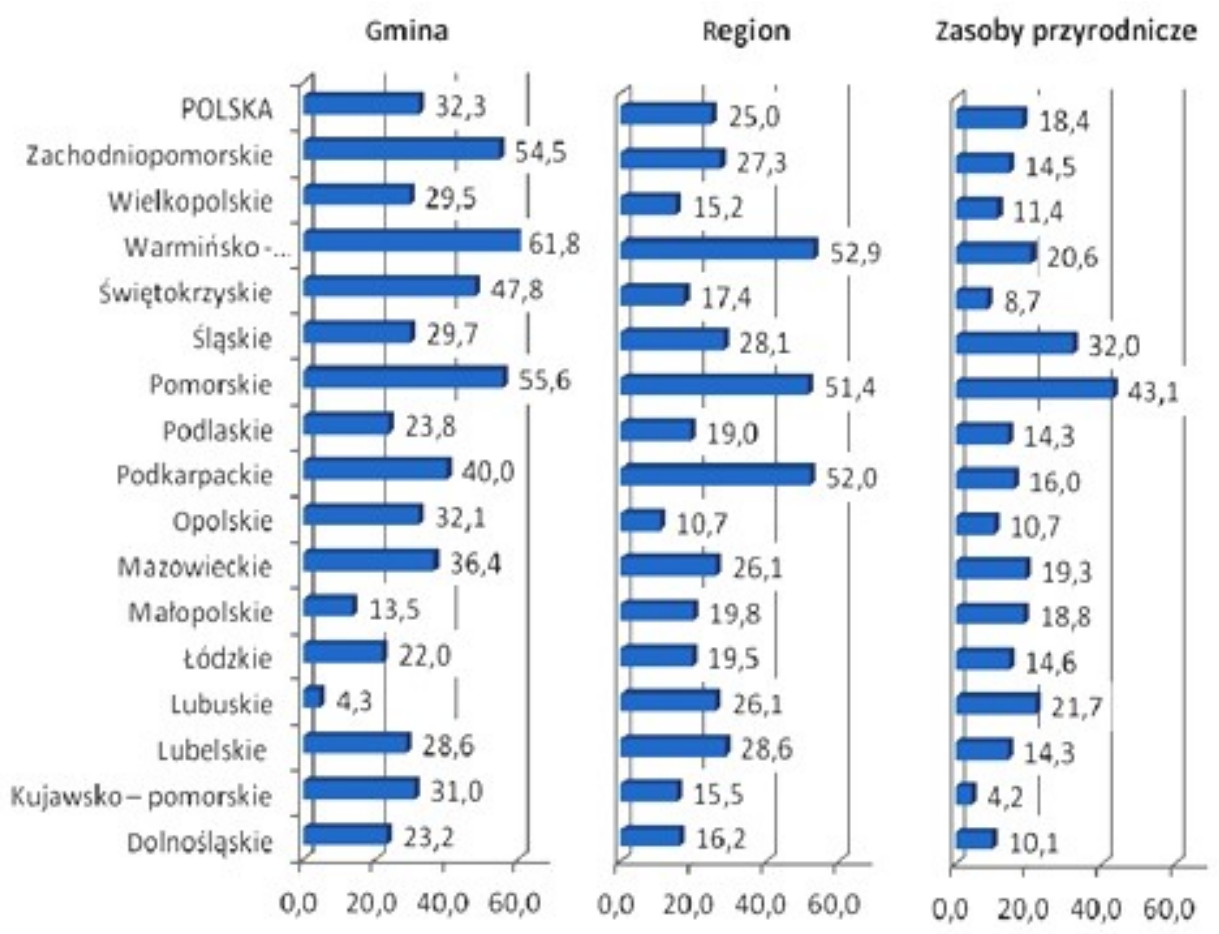

Rys. 7. Imprezy biegowe promujące miejsce ich odbywania

Źródło: opracowanie własne na podstawie http://www.maratonypolskie.pl, (20.10.2016).

Z kolei najmniej biegów mających wśród swoich celów promocję obszaru ulokowane jest $\mathrm{w}$ dolnośląskim i kujawsko-pomorskim. Przy czym najsłabszą reprezentację promocji gminy mają imprezy województwa lubuskiego $(4,3 \%)$, a walorów przyrodniczych kujawsko-pomorskiego (4,2\%). Promocja regionu pojawia się w celach imprez częściej, najniższą wartość zanotowano dla opolskiego $(10,7 \%)$. 


\section{Podsumowanie}

Przyczyny organizacji imprez biegowych mają zwykle rodowód oddolny. Nawet jeśli bieg ma organizatora $w$ postaci instytucji, organizacji, władz samorządowych, czy podmiotu gospodarczego, za każdą taką imprezą kryją się konkretne osoby. Potrzeba pasjonata sportu, może biegacza, ale na pewno społecznika, który porwie za sobą grono innych zapaleńców, zgromadzi wokół siebie wolontariuszy, pozyska sponsorów i poświęcając swój prywatny czas zorganizuje bieg uliczny, lub bardziej oryginalną imprezę zlokalizowaną w ciekawym miejscu. To właśnie $\mathrm{z}$ miejscem tego typu przedsięwzięcie jest silnie związane. To wybór lokalizacji decyduje często o atrakcyjności biegu, stając się wręcz obiektem marzeń potencjalnych uczestników (np. maraton w Nowym Jorku). $\mathrm{Z}$ tej to przyczyny bieg jest doskonałą okazją do upowszechniania wiedzy o miejscu jego rozgrywania, kreowania wizerunku, atrakcyjności turystycznej obszaru i przyciągania turystów. Z okazji tej powinny więc masowo korzystać samorządy terytorialne, które w swoich zadaniach mają zapisany, nie tylko obowiązek dbałości o kulturę fizyczną mieszkańców, ale też promocji regionu. Często, jeśli organizatorem biegu jest inny podmiot, promocja ta nie wymaga ze strony samorządu żadnego wysiłku. Zdarza się, że odbywa się ona całkiem poza jego udziałem i wiedzą, a cele promocji regionu zapisane są w regulaminach biegów, w żaden sposób niepowiązanych z jego wspóluczestnictwem. Dość powiedzieć, że liczba imprez promujących gminę i region przewyższa te, których organizatorami lub współorganizatorami są gminy lub powiaty.

Tak więc, w organizację co trzeciej, sklasyfikowanej w badaniach imprezy zaangażowany jest samorząd gminny, natomiast powiaty wystąpily w $14 \% \mathrm{im}$ prez, a województwa w żadnej. Analizując stopień wykorzystania imprez do promocji regionu, również co trzecia impreza biegowa zakłada promocję gminy (miasta), co czwarta natomiast regionu, a co piąta walorów przyrodniczych. Nie jest to, zdaniem autorek, poziom zadowalający. Samorządy nie dostrzegają jak dotąd potencjału, jaki niesie ze sobą nagromadzenie sporej ilości ludzi (w tym osób z zewnątrz) na własnym terytorium dla propagowania wiedzy o jego walorach. Pocieszeniem niech więc będzie fakt, że niezależnie od ich woli i zapisów w regulaminie, impreza biegowa i tak przyczynia się do wzrostu wiedzy o regionie, a jeśli jest przy tym udana, wiedzy tej towarzyszą miłe wspomnienia, niezapomniane przeżycia i nierzadko chęć powrotu w przyjazne otoczenie. 


\section{Bibliografia}

Czajkowska-Matosiuk K., Aplikacje prawnicze w pytaniach i odpowiedziach, C.H. Beck, Warszawa 2014.

Konstytucja Rzeczypospolitej Polskiej z 2 kwietnia 1997 r. DzU 1997 r. nr 78, poz. 483;

Leksykon budżetowy Sejmu Rzeczypospolitej Polskiej http://sejm.gov.pl/Sejm7.nsf/ BASLeks ykon.xsp?id=ADCDAB77EB4E2875C1257A6100370ABA\&litera=S\&S ession ID=lhuwpqzh (dostęp 20.10.2016).

Ustawa o samorządzie gminnym, z dnia 8.03.1990, Załącznik do obwieszczenia Marszałka Sejmu Rzeczpospolitej Polskiej z 17 marca 2016 w sprawie ogłoszenia jednolitego tekstu ustawy o samorządzie gminnym, DzU z 2016 r. poz. 446.

Ustawa z 24 kwietnia 2003 r. O działalności pożytku publicznego i o wolontariacie, DzU 2016 r. poz. 239.

Ustawa z 24 lipca 1998 r. O wprowadzeniu zasadniczego trójstopniowego podziału terytorialnego państwa. DzU nr 96 poz. 603.

Ustawa z 25 czerwca 2010 r. O sporcie DzU z 2014 r. poz. 715 z późn. zm.

Ustawa z 27 sierpnia 2009 r. O finansach publicznych, DzU 2009 nr 157 poz. 1240.

Ustawa z 5 czerwca 1998 o samorządzie powiatowym. DzU 1998 nr 91 poz. 578.

Ustawa z 5 czerwca 1998 r. o samorządzie województwa. DzU 1998 nr 91 poz. 576.

W jakiejformiesa OSiRy, sportplus, 05/2012; http://www.es portplus.pl/index.php?act=article \&sub= view\&id=8287 (dostęp 18.10.2016).

www.arc.com.pl/polacy_docenili_sport-40999562-p1.html, (dostęp 20.10.2016).

www.maratonypolskie.pl/mp_index.php, (dostęp 20.10.2016).

\section{Local government and its participation in the organization of running events}

\section{Summary}

The aim of the article is to evaluate the interest of local government in the organization (or co-participation in the organization) of running events taking place within their boundaries, as well as, the degree of running events being used to promote the region and its natural values. To assess the involvement of local governments in the organisation process, running events held in Poland in the second half of 2016 were analysed. Based on the available regulations, 964 running events were classified by the organizer of the run and the purpose of the event. The obtained data shows that local councils are involved in the organization of every third event; and boroughs in $14 \%$. Among the local governments, Podkarpackie district is pre-eminent and Malopolskie displays the lowest level of involvement. Regarding objectives, every third running event is designed to promote municipality, every fourth - region, and every fifth - natural values. These objectives are mostly present in events taking place in Pomorskie and 
Warmińsko - Mazurskie district. The weakest emphasis on the promotion of municipality during the running events puts Lubuskie, region - Opolskie and natural assets Kujawsko-Pomorkie district.

Translated by Elżbieta Nazari 